\title{
EFFECT OF LABILE INORGANIC PHOSPHATE STATUS AND ORGANIC CARBON ADDITIONS ON THE MICROBIAL UPTAKE OF PHOSPHORUS IN SOILS
}

\author{
B. S. CHAUHAN ${ }^{1}$, J. W. B. STEWART, and E. A. PAUL ${ }^{2}$
}

Saskatchewan Institute of Pedology, University of Saskatchewan, Saskatoon, Sask. $S 7 N$ OWO. Contribution no. R249, received 22 Oct. 1980 , accepted 27 Jan. 1981.
Chauhan, B. S., Stewart, J. W. B. and Paul, E. A. 1981. Effect of labile inorganic phosphate status and organic carbon additions on the microbial uptake of phosphorus in soils. Can. J. Soil Sci. 61: 373-385.

The effect of labile inorganic phosphate $\left(\mathrm{P}_{\mathrm{i}}\right)$ status of the soil on the decomposition of added cellulose and on the immobilization, mineralization, and redistribution of native and added $P$ in soils was studied in a greenhouse incubation experiment. Cellulose was added at $765 \mu \mathrm{g} \mathrm{C} \cdot \mathrm{g}^{-1}$ soil with and without $\mathrm{P}\left(9 \mu \mathrm{g} \cdot \mathrm{g}^{-1}\right.$ soil) every 30 days under adequate $\mathrm{N}, \mathrm{H}_{2} \mathrm{O}$, and constant tempreature to two soils of different available $P$ status. Lack of $\mathrm{P}$ eventually slowed down decomposition of added $\mathrm{C}$, but this effect was partially compensated for by increased mineralization of organic $P\left(P_{0}\right)$ forms. Added $P$ was redistributed to both $\mathrm{P}_{i}(58-69 \%)$ and $\mathrm{P}_{0}(42-31 \%)$ forms; higher amounts of $\mathrm{P}_{0}$ were found in the soil with the highest $P_{i}$ status. The correlation between microbial $P$ uptake and solution $P$ values was significant, and microbial $C: P$ ratios ranged from $12: 1$ under high available $\mathrm{P}$ conditions to $45: 1$ where $\mathrm{P}$ was in low supply.

Les effets de la situation des phosphates inorganiques labiles $\left(\mathrm{P}_{\mathrm{i}}\right)$ du sol sur la décomposition de la cellulose incorporée, et sur l'immobilisation, la minéralisation et la redistribution du P originel et ajouté ont été étudiés en serre nous incubation. Des apports de cellulose correspondant à $765 \mu \mathrm{g} \mathrm{C} / \mathrm{g}$ de sol ont été effectués tous les trente jours avec ou sans fertilisation $\mathrm{P}(9 \mu \mathrm{g} / \mathrm{g}$ sol), en présence d'un régime d'alimentation hydrique et azotée adéquat et à température constante sur deux sols à bilan $P$ différent. La pénurie de $\mathrm{P}$ a, à la longue, ralenti la décomposition du C d'appoint, mais l'effet a été partiellement compensé par la minéralisation accrue des formes organiques de $\mathrm{P}\left(\mathrm{P}_{\mathrm{o}}\right)$. Le $\mathrm{P}$ de fumure s'est réparti entre les formes inorganiques $(58-69 \%)$ et organiques $(42-31 \%)$ et, en outre, de plus fortes concentrations de $P_{0}$ ont été retrouvées dans le sol à bilan $\mathrm{P}$ élevé. La corrélation obtenue entre le taux d'absorption de $\mathrm{P}$ par les mico-organismes et les valeurs de $\mathrm{P}$ en solution était significative et le rapport $\mathrm{C} / \mathrm{P}$ fluctuait de 12:1 en régime de forte disponibilité de $\mathrm{P}$ à $45: 1$ en situation de faible diponibilité.

The development of techniques to measure the amount of phosphorus ( $P$ ) and other nutrients released from soil biomass upon fumigating (lysing) microbial cells (Jenkinson and Powlson 1976) coupled with more accurate staining methods for measuring microbial biomass (Babiuk and Paul 1970; Paul and Johnson 1977) have provided the means of examining the dynamics of $P$ cycling in soils (Cosgrove 1977; Cole et al. 1977). In an earlier investigation (Chauhan et al. 1979) of aspects of $P$ cycling in a

Present address (B.S.C.): College of Agriculture, Medzipherra, Chaspani, Nagaland, India.

Present address (E.A.P.): Department of Plant and Soil Biology, University of California, Berkeley, California, U.S.A.

Can J. Soil Sci. 61: 373-385 (May 1981) 
Chernozemic Black soil, the rate of $\mathrm{P}$ movement between soil inorganic $\left(\mathrm{P}_{\mathrm{i}}\right)$, organic $\left(\mathrm{P}_{\mathrm{o}}\right)$, and biomass $\left(\mathrm{P}_{\mathrm{m}}\right) \mathrm{P}$ compartments was measured following regular additions of grass and cellulose. The total content of $\mathrm{P}$ in microbial biomass was affected only slightly by addition of organic residue and/or fertilizer $P$ to a soil with a high available $\mathrm{P}$ status ( 34 $\mu \mathrm{g} \cdot \mathrm{g}^{-1}$ resin-extractable $\left.\mathrm{P}\right)$. The addition of fertilizer $P$ did not change the percentage of added cellulose $-\mathrm{C}(47 \%)$ remaining in the soil after 9 mo incubation. The monthly addition of cellulose without fertilizer $P$ depleted

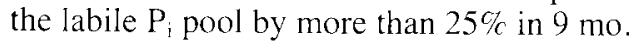
This suggested that the continued addition of cellulose without $P$ for a longer period of time would eventually have exhausted the reserve of labile $\mathrm{P}_{\mathrm{i}}$ leaving the microbial population dependent on the rate of mineralization of $P_{0}$ forms.

To examine the above hypothesis the dynamics of $\mathrm{P}$ within the soil system were examined in two soils representing high- and low-labile $\mathrm{P}_{\mathrm{i}}$ status. This investigation had the objectives of (a) measuring the change in $P$ forms (labile $P_{1}$ and $P_{o}$ ) with time in two soils of different $P_{i}$ status to which $C$ sources were added every 30 days, and (b) relating these transfers to microbial activity.

\section{MATERIALS AND METHODS}

Two soils, the $\mathrm{Bm}$ horizon of a Chernozemic Black soil (29\% clay. $2.0 \%$ organic $\mathrm{C}$, and $\mathrm{pH} 7.8$ ) of the Oxbow Association and the Ap horizon of a Chernozemic Dark Brown soil (17\% clay, 2.3\% organic $\mathrm{C}$, and $\mathrm{pH} 6.8$ ) of the Bradwcll Association (Canada Soil Survey Committee 1978), were used in this experiment. These soils were air-dried at room temperature, ground to pass a $2-\mathrm{mm}$ sieve, and thoroughly mixed prior to use. The available $P$ status of the Bradwell soil (resin-extractable P$49.1 \mu \mathrm{g} \cdot \mathrm{g}^{-1} . \quad \mathrm{NaHCO}_{3}$-extractable $\mathrm{P}-18.0$ $\mu \mathrm{g} \cdot \mathrm{g}^{-1}$ ) was much higher than that of the Oxbow soil (resin extractable P-4.4 $\mu \mathrm{g} \cdot \mathrm{g}^{-1}, \mathrm{NaHCO}_{3}-$ extractable P-3.0 $\mu \mathrm{g} \cdot \mathrm{g}^{-1}$ ). In the first treatment, cellulose $(43 \% \mathrm{C}$ ) was added at a rate equivalent to $765 \mu \mathrm{g} \mathrm{C} \cdot \mathrm{g}^{-1}$ every 30 days. In a second treatment cellulose was added at the same rate, and $\mathrm{P}$ as $\mathrm{KH}_{2} \mathrm{PO}_{4}$ was added at a rate equivalent to 9 $\mu \mathrm{g} \cdot \mathrm{g}^{-1}$ soil. In the third treatment the same quanti- ty of $\mathrm{P}$ was added without the addition of $\mathrm{C}$, and in the fourth treatment the original soil was incubated without addition of either $\mathrm{C}$ or P. Ammonium nitrate was used to adjust the $\mathrm{C}: \mathrm{N}$ ratio of the cellulose treatment to 25:1. Required amounts of cellulose, $\mathrm{N}$, and $\mathrm{P}$ were added and thoroughly mixed into soil every 30 days and incubated at field capacity at $24 \pm 2^{\circ} \mathrm{C}$. Algal growth on the surface of the soils was prevented by covering the surface of the pots with styrofoam beads. Moisture adjustments were made every second day.

Triplicate, 1-kg soil samples were used. At the end of each incubation period, 50-g subsamples were removed from each larger sample before further $\mathrm{C}$ or $\mathrm{P}$ additions. These subsamples were similarly treated with proportional additions of $\mathrm{C}$ and $\mathrm{P}$, incubated in the same environmental conditions, but sampled at different times, depending on the stage of decomposition in the 30-day incubation period. An extra series of 50-g soil samples receiving the same treatment was incubated separately in airtight desiccators containing known volumes of standardized $\mathrm{NaOH}$ solution. This enabled daily measurements of $\mathrm{CO}_{2}$ evolution to be taken. The latter series of incubations were started 5 days in advance of the main experiment: the rates of $\mathrm{CO}_{2}$ production could thus be used to determine the times of sampling in the larger experiment. Measurements of microbial biomass, $\mathrm{CO}_{2}$ evolution. $\mathrm{NaHCO}_{3}$-extractable $\mathrm{P}_{i}$ and $\mathrm{P}_{0}$-extractable $\mathrm{P}$, $\mathrm{P}_{\mathrm{m}}$. solution $\mathrm{P}$, and resin-extractable $\mathrm{P}$ were taken at the time of the maximum decomposition rate of the added organic materials, as determined by $\mathrm{CO}_{2}$ production, and at a later stage when the $\mathrm{CO}_{2}$ production had levelled off and approximately reached steady state conditions. At the end of the 9-mo incubation period, the total soil $\mathrm{P}$ was fractionated into various $\mathrm{P}_{I}$ and $\mathrm{P}_{\mathrm{O}}$ forms. Experimental details have been described previously (Chauhan et al. 1979).

The methods of analyses used in this study are presented in Table 1. Further details are given below for some of the more recently developed techniques.

\section{Microbial $\mathbf{P}\left(\mathbf{P}_{\mathrm{m}}\right)$}

Paired soil samples (air-dried $<2 \mathrm{~mm}$ ), one chloroform-treated and one untreated, were extracted at a 1:20 soil solution ratio with $0.5 \mathrm{M}, \mathrm{pH}$ $8.5 \mathrm{NaHCO}_{3}(\mathrm{Olsen}$ et al. 1954). The difference in total $P$ in the two extracts was found to approximate $25 \%$ of the total $P_{m}$ in the two soils under study (Hedley and Stewart, Unpubl. data, Univ. 
Sask). Liquid chloroform was applied directly to soils $(1: 1 \mathrm{wt} / \mathrm{vol})$ for $30 \mathrm{~min}$, then removed by aeration with a fan in a fumehood at $45^{\circ} \mathrm{C}$. Chloroform-free dried samples were stored at room temperature for 6 days before extraction with $\mathrm{NaHCO}_{3}$.

Moisture content and specific gravity of soil isolates were used to convert microscopic biovolume measurements to biomass (Van Veen and Paul 1979). This resulted in a multiplication of the bacterial biomass as calculated from literature values (Babiuk and Paul 1970) by a factor of 3.63 . The fungal biomass was increased by a factor of

Table 1. Analytical methods used in this study

\begin{tabular}{|c|c|}
\hline Methods & Reference \\
\hline $\begin{array}{l}\mathrm{NaHCO}_{3} \text {-extractable } \mathrm{P} \\
\text { (i) inorganic }\left(\mathrm{P}_{i}\right) \\
\text { (ii) organic }\left(\mathrm{P}_{0}\right)\end{array}$ & $\begin{array}{l}\text { Olsen et al. (1954) } \\
\text { Halm et al. (1972): Bow- } \\
\text { man and Cole (1978a) }\end{array}$ \\
\hline $\begin{array}{l}\text { Microbial } \mathrm{P}\left(\mathrm{CHCl}_{3}\right. \\
\text { treatment }+\mathrm{NaHCO}_{3} \\
\text { extraction after } 6 \text { days })\end{array}$ & $\begin{array}{l}\text { Chauhan et al. (1979): } \\
\text { Jenkinson et al. (1979) }\end{array}$ \\
\hline $\begin{array}{l}\text { Total (mineral and } \\
\text { organic P) }\end{array}$ & $\begin{array}{l}\text { Saunders and Williams } \\
\text { (1955) (modified to } \\
\text { use } 2 \mathrm{~N} \mathrm{H}_{2} \mathrm{SO}_{4} \text { ), Hals- } \\
\text { tead and } \mathrm{McKercher} \\
\text { (1975) }\end{array}$ \\
\hline Inorganic $\mathrm{P}$ fractions & $\begin{array}{l}\text { Peterson and Corey } \\
\text { (1966) (modified for } \\
\text { calcareous soils by } \\
\text { Sadler and Stewart } \\
\text { (1975)) }\end{array}$ \\
\hline Resin-extractable $\mathrm{P}$ & Sibbesen (1977) \\
\hline Organic P fractions & $\begin{array}{l}\text { Bowman and Cole } \\
\text { (1978b) }\end{array}$ \\
\hline $\begin{array}{l}\text { Microbial biomas } \\
\text { Bacteria } \\
\text { Fungi }\end{array}$ & $\begin{array}{l}\text { Babiuk and Paul ( } 1970) \\
\text { (modified by Van } \\
\text { Veen and Paul } \\
(1979) \text { ) } \\
\text { Paul and Johnson (1977) } \\
\text { (modified by Van } \\
\text { Veen and Paul } \\
(1979) \text { ) }\end{array}$ \\
\hline \multicolumn{2}{|l|}{$\begin{array}{l}\mathrm{CO}_{2} \text { evolution }(\mathrm{NaOH} \\
\text { absorbent in closed } \\
\text { container) }\end{array}$} \\
\hline ATP & Paul and Johnson (1977) \\
\hline Total C (dry combustion) & Allison (1965) \\
\hline Solution P & $\begin{array}{l}\text { Sadler and Stewart } \\
\text { (1977) }\end{array}$ \\
\hline
\end{tabular}

1.44. In the case of fungi the dry weight specific gravity value of 1.44 could represent an organism with a specific gravity of 1.3 and a moisture content of $76 \%$.

\section{RESULTS}

Net changes in the organic $C$ contents of the two soils following a 9-mo incubation with and without cellulose and/or $\mathrm{P}$ can be determined from the data for organic $C$ content of the two soils (Table 2). Carbon determinations indicate that the Oxbow Bm treated with $\mathrm{C}+\mathrm{N}+\mathrm{P}$ still contained $4600 \mu \mathrm{g}(67 \%)$ of the $6885 \mu \mathrm{g} \mathrm{C}$ added during the 9-mo incubation period. The Bradwell Ap retained less of the $\mathrm{C}$ with only an additional $4000 \mu \mathrm{g}(58 \%)$ being found in the $\mathrm{C}+\mathrm{N}+\mathrm{P}$ treatment. The addition of $\mathrm{C}+\mathrm{N}$ without $\mathrm{P}$ resulted in the retention of slightly greater amounts of $\mathrm{C}$. Compared with the control soils, addition of $P$ alone had no significant effect on soil $C$ content.

Summation of the daily $\mathrm{CO}_{2}-\mathrm{C}$ values and subtraction of data for the control indicate (Fig. 1) that $57 \%$ of the added $\mathrm{C}$ remained in the Oxbow Bm after 180 days in the cellulose $+\mathrm{N}$ treatment with $53 \%$ of the added $\mathrm{C}$ remaining in the cellulose $+\mathrm{N}+\mathrm{P}$ treatment. The Bradwell Ap retained 43 and $39 \%$ of the added $C$ in the cellulose treatments without and with added $P$, respectively. Further additions of $\mathrm{C}$ for another 3 mo resulted in a greater percentage of added $C$ $(47 \%)$ being retained in the treatment without $\mathrm{P}$, whereas with $\mathrm{P}$ the same percentage $(39 \%)$ was retained. In contrast, Chauhan et al. (1979) found in the Oxbow Ap soil that $47 \%$ of the added $C$ remained after 180 days and

Table 2. Percent organic carbon content of the original soils after 9 mo of incubation (average of two replications $\pm \mathrm{SE}$ )

\begin{tabular}{lcc}
\hline \multicolumn{1}{c}{ Treatments } & $\begin{array}{c}\text { Oxbow }(\mathrm{Bm}) \\
(\% \mathrm{C})\end{array}$ & $\begin{array}{c}\text { Bradwell }(\mathrm{Ap}) \\
(\% \mathrm{C})\end{array}$ \\
\hline $\begin{array}{l}\text { Original soil } \\
\text { Incubated soils }\end{array}$ & $1.97 \pm 0.11$ & $2.34 \pm 0.11$ \\
$\quad$ Control & $1.88 \pm 0.05$ & $2.21 \pm 0.07$ \\
$\quad$ Cellulose $+\mathrm{N}$ & $2.42 \pm 0.09$ & $2.64 \pm 0.05$ \\
$\quad$ Cellulose $+\mathrm{N}+\mathrm{P}$ & $2.34 \pm 0.11$ & $2.61 \pm 0.14$ \\
P treatment & $1.88 \pm 0.09$ & $2.20 \pm 0.09$ \\
\hline
\end{tabular}


the addition of $\mathrm{P}$ and $\mathrm{C}$ did not make any difference to $\mathrm{CO}_{2}$ evolution.

The pattern of $\mathrm{CO}_{2}$ evolution in the two soils indicates differences in the mode of attack on the added substrate. The Bradwell Ap horizon showed a rapid rise in $\mathrm{CO}_{2}$ production upon the addition of cellulose at the beginning of each 30-day period. However, the height of the pulse attributed to added $\mathrm{C}$ decreased with each subsequent cellulose addition until, after 150 days, the increase in $\mathrm{CO}_{2}$ evolution upon addition of extra substrate was only twofold. The Oxbow Bm showed significant pulses only after the first two additions.

Phosphorus additions increased the height of the $\mathrm{CO}_{2}$ pulse. However, even with $\mathrm{P}$ additions, the $\mathrm{CO}_{2}$ levels soon stabilized throughout the incubation period. The change from essentially first-order to zero-order kinetics, during which the rate of substrate transformation was unaffected by substrate concentration, showed that some factor besides $P$ availability controlled substrate degradation, such that $\mathrm{CO}_{2}$ evolution rates achieved a similar pattern of approximately

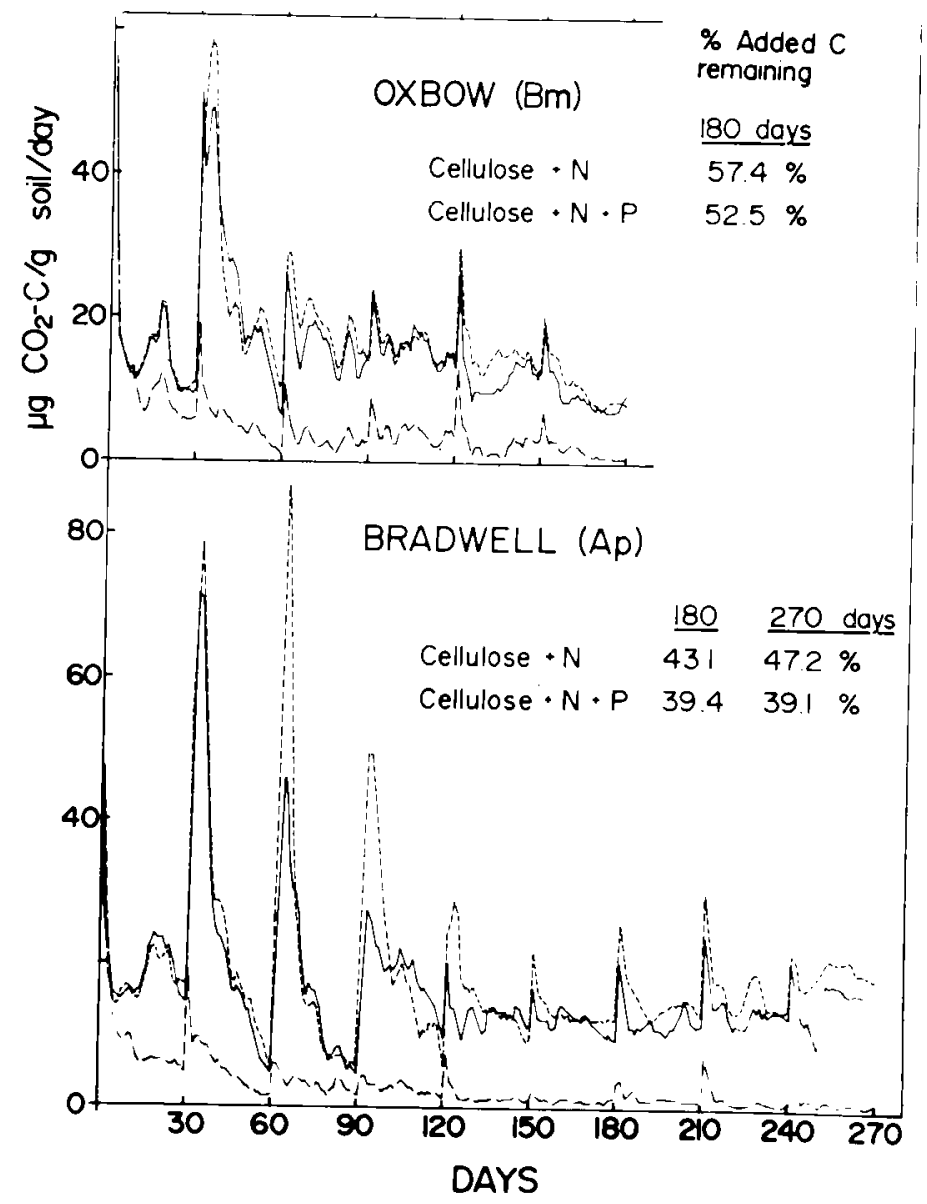

Fig. 1. Daily measurements of the $\mathrm{CO}_{2}-\mathrm{C}$ produced per gram soil per day in the control and cellulose amended soils. Cellulose was added every 30 days at $765 \mu \mathrm{g} \mathrm{C} \cdot \mathrm{g}^{-1}$ soil. 
$20 \mu \mathrm{g} \mathrm{CO} \mathrm{CO}_{2} \mathrm{C} \cdot \mathrm{g}^{-1} \cdot$ day $^{-1}$ in all soils studied. Only the Oxbow Bm, with original resinextractable $P$ and solution $P$ values of 4.4 and $0.08 \mu \mathrm{g} \cdot \mathrm{g}^{-1}$, respectively, could be stated to be deficient in $P$. Equivalent values for the Bradwell soil were 49.1 and $0.8 \mu \mathrm{g} \cdot \mathrm{g}^{-1}$.

Estimates of combined bacterial and fungal $\mathrm{C}$ at different sampling times with treatment (Table 3 ) show that the addition of cellulose to both soils increased microbial $\mathrm{C}$ by a factor of 1.5 to 2.0. Values obtained at maximum $\mathrm{CO}_{2}-\mathrm{C}$ productivity were higher than at the end of the incubation period (steady state) in the first two incubations. Average combined microbial $\mathrm{C}$ values obtained over the nine sampling dates in cellulose treatments were marginally higher in the Oxbow soil than in the Bradwell soil.

Net changes in $P_{i}$ and $P_{o}$ fractions in the Oxbow Bm and Bradwell Ap soil following a 9-mo incubation with and without cellulose and added fertilizer $P$ can be determined from the data in Table 4 . The recovery of added $P$ $\left(81 \mu \mathrm{g} \cdot \mathrm{g}^{-1}\right.$ soils) ranged from 98 to $111 \%$. When the fertilizer $\mathrm{P}$ was added with cellulose, $58-69 \%$ of the added $\mathrm{P}$ was found in $\mathrm{P}_{\mathrm{i}}$ forms. The addition of $\mathrm{C}$ without extra fertilizer $\mathrm{P}$ decreased the total $\mathrm{P}_{\mathrm{i}}$ content by $15-25 \mu \mathrm{g} \mathrm{P} \cdot \mathrm{g}^{-1}$ soil and increased $P_{o}$ by similar amounts. The addition of $\mathbf{P}$ fertilizer without a $\mathrm{C}$ substrate followed by incubation did not significantly alter the $P_{o}$ content of either soil, and the added $\mathrm{P}$ was found in inorganic forms.

The two main indices of labile $\mathrm{P}_{\mathrm{i}}$ in soils (resin-extractable $\mathrm{P}$ and $\mathrm{NaHCO}_{3}$-extractable $\mathrm{P}_{\mathrm{i}}$ ) showed that the soils differed greatly in their ability to supply $P$ (Table 4 ). The resinextractable $P$ was $4.4 \mu \mathrm{g} \cdot \mathrm{g}^{-1}$ in the original Oxbow soil, whereas in the Bradwell Ap soil the resin-extractable $\mathbf{P}$ was $49.1 \mu \mathrm{g} \cdot \mathrm{g}^{-1}$ soil. The differences in original solution $P$ concentrations were also approximately tenfold, and both labile $\mathrm{P}_{\mathrm{i}}$ indices correlated signficiantly with solution $P$ values $(P<0.001)$ at each sampling date. Addition of $\mathrm{C}$ followed by incubation decreased the resin-extractable $\mathrm{P}$ in both soils. In the Oxbow soil, $3 \mu \mathrm{g} \mathrm{P} \cdot \mathrm{g}^{-1}$ soil were immobilized; whereas in the Bradwell soil, which had a greater supply of labile $\mathrm{P}, 11 \mu \mathrm{g} \mathrm{P} \cdot \mathrm{g}^{-1}$ soil were removed from the resin-extractable fraction by $\mathrm{C}$ addition and incubation. Similar trends could be seen with the $\mathrm{NaHCO}_{3}$-extractable $\mathrm{P}_{\mathrm{i}}$ value. Both these labile $\mathrm{P}$ indices were greatly increased by addition of fertilizer $\mathrm{P}$, but when $\mathrm{C}$ was added with the fertilizer $P$, the increase in the labile $P$ indices was not as great as when $P$ fertilizer was added alone.

Cellulose additions without fertilizer $\mathrm{P}$ decreased $\mathrm{NH}_{4} \mathrm{Cl}$ - and $\mathrm{NH}_{4} \mathrm{~F}$-extractable $\mathrm{P}_{\mathrm{i}}$ forms in both soils (Table 5) although the size of the decrease was much larger in the Bradwell soil than in the Oxbow soil. These

Table 3. Combined bacterial and fungal $\mathrm{C}\left(\mu \mathrm{g} \mathrm{C} \cdot \mathrm{g}^{1}\right.$ soil) at different sampling times in two soils incubated after different $C+P$ treatment (values presented are the mean of duplicate analyses; $S D<15 \%$ )

\begin{tabular}{|c|c|c|c|c|c|c|c|c|c|c|}
\hline \multirow[b]{2}{*}{ Treatment } & \multicolumn{9}{|c|}{ Sampling time (days) } & \multirow[b]{2}{*}{$\overline{\mathrm{X}}$} \\
\hline & 5 & $20 \div$ & 30 & $34 \div$ & 90 & $84 \dagger$ & 120 & $124 \dagger$ & 150 & \\
\hline \multicolumn{11}{|c|}{ Oxbow $(\mathrm{Bm})$} \\
\hline Controlt & $185 \S$ & 215 & 170 & 268 & 181 & 177 & 161 & 163 & 145 & 185 \\
\hline Cellulose $+\mathrm{N}$ & 193 & $309 \S$ & 277 & 356 & 441 & 466 & 448 & 447 & 395 & 370 \\
\hline Cellulose $+\mathrm{N}+\mathrm{P}$ & 342 & 279 & 292 & 382 & 286 & 392 & 454 & 387 & 356 & 352 \\
\hline \multicolumn{11}{|c|}{ Bradwell (Ap) } \\
\hline Controlf: & 261 & 229 & 180 & 329 & 157 & 218 & 160 & 186 & 159 & 208 \\
\hline Cellulose $+N$ & 275 & 393 & 224 & 533 & 244 & 357 & 313 & 404 & 300 & 338 \\
\hline Cellulose $+N+P$ & 282 & 287 & 282 & 513 & 210 & 393 & 319 & 390 & 280 & 328 \\
\hline
\end{tabular}

$\mp$ Maximum $\mathrm{CO}_{2}$ evolution

$\$$ Average of microbial $C$ in control and soil $+P$ treatments.

$\S \mathrm{SD}<20 \%$. 
two fractions constitute the major source of labile $P_{i}$ in calcareous soils (Sadler and Stewart 1975). Addition of $P$, either alone or with $C$, increased the first four $P_{i}$ fractions in both soils and the $\mathrm{NaOH}$-extractable $\mathrm{P}$ in the Oxbow soil. The effect of $\mathrm{C}$ additions on added $\mathrm{P}$ distribution was to decrease $\mathrm{NH}_{4} \mathrm{Cl}$ and $\mathrm{NH}_{4} \mathrm{~F}$-extractable $\mathrm{P}_{\mathrm{i}}$ significantly in both soils. In the Oxbow soil $\mathrm{NaOH}-\mathrm{NaCl}$ extractable $\mathrm{P}$ was also significantly decreased and the other two $P_{i}$ fractions were lower. The increase in reductant-soluble $\mathrm{P}$ on $\mathrm{P}$ addition was greater in the Oxbow soil of lower $\mathrm{pH}$ value, suggesting that secondary inorganic $P$ of lower availability was being formed. No change was noted in the Bradwell soil in $\mathrm{NaOH}-$ and $\mathrm{H}_{2} \mathrm{SO}_{4}$-extractable $\mathrm{P}_{\mathrm{j}}$ fractions, which are thought to be more insoluble $\mathrm{Fe}$ bound, and primary mineral (hydroxy apatite) $\mathrm{P}$, respectively; but in the Oxbow soil some changes were noted in the $\mathrm{NaOH}$ extractable $P_{i}$, suggesting that it may be utilized as a $P$ source when labile $P_{I}$ is very low.
Incubation of the soil without $\mathrm{C}$ amendments resulted in changes in the distribution of $\mathrm{P}_{\mathrm{o}}$ in both soils (Table 5); the alkalihydrolyzable and humic $-P$ decreased while fulvic $P$ increased. Incubation without added $P$ but with $C$ increased total $P_{0}$. Most of the increase occurred in the $\mathrm{H}_{2} \mathrm{SO}_{4}$-extractable and fulvic $\mathrm{P}$ fractions. Decreases in alkalihydrolyzable $P$ values were noted in both soils but the decrease was much larger in the Oxbow (Bm) soils. Humin -P values also increased in this treatment in both soils, but these results were obtained by difference between total $P_{o}$ and the sum of the other $P_{0}$ fractions and cannot be considered to be significantly different. Incubation with both added $\mathrm{P}$ and $\mathrm{C}$ showed significant increases in $\mathrm{H}_{2} \mathrm{SO}_{4}$-extractable $\mathrm{P}$ and fulvic $-\mathrm{P}$ with no significant change from the C-alone incubation in any other $\mathrm{P}_{\mathrm{o}}$ fraction.

The $\mathrm{NaHCO}_{3}$-extractable $\mathrm{P}_{\mathrm{i}}, \mathrm{P}_{\mathrm{o}}$ and $\mathrm{P}_{\mathrm{m}}$ values (data not shown), at various sampling dates corresponding to the maximum decom-

Table 4. Total organic and inorganic $P$ and labile $P$ indexes in the original soils and after 9 mo of incubation. All results are expressed as $\mu \mathrm{gP} \cdot \mathrm{g}^{-1}$ oven-dry soil and are the average of three determinations of each of three replicates

\begin{tabular}{|c|c|c|c|c|c|}
\hline & $\begin{array}{l}\text { Original } \\
\text { soil }\end{array}$ & $\begin{array}{l}\text { Control } \\
\text { soil }\end{array}$ & $\begin{array}{l}\text { Cellulose }+\mathrm{N}- \\
\text { treated soil }\end{array}$ & $\begin{array}{l}\text { Cellulose }+\mathrm{N}+\mathrm{P}-\vec{\uparrow} \\
\text { treated soil }\end{array}$ & $\begin{array}{c}\text { P-treated } \dagger \\
\text { soil }\end{array}$ \\
\hline & & 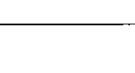 & $\begin{array}{l}-\mu \mathrm{g} \cdot \mathrm{g}^{-1} \text { soil } \\
\quad \text { Oxbow }(B\end{array}$ & & \\
\hline \multicolumn{6}{|l|}{ Total $\mathrm{P}$} \\
\hline Soil P & $563 \pm 10$ & $565 \pm 12$ & $563 \pm 13$ & $645 \pm 16$ & $655 \pm 21$ \\
\hline Inorganic $\mathrm{P}$ & $250 \pm 4$ & $254 \pm 8$ & $239 \pm 7$ & $310 \pm 10$ & $338 \pm 14$ \\
\hline Organic $\mathrm{P}_{\stackrel{1}{!}}^{\dagger}$ & 313 & 311 & 327 & 335 & 317 \\
\hline \multicolumn{6}{|l|}{ Labile $P$ indices } \\
\hline Resin-extractable $\mathrm{P}$ & $4.4 \pm 0.7$ & $6.1 \pm 1.0$ & $3.3 \pm 0.6$ & $35.6 \pm 6.2$ & $49.6 \pm 11.2$ \\
\hline Solution P & 0.08 & 0.08 & 0.03 & 0.52 & 1.04 \\
\hline \multirow[t]{2}{*}{$\mathrm{NaHCO}_{3}$-extractable $\mathrm{P}$} & $3.0 \pm 0.4$ & $3.9 \pm 0.2$ & $1.0 \pm 0.1$ & $20.9 \pm 1.1$ & $27.9 \pm 0.3$ \\
\hline & \multicolumn{5}{|c|}{ Bradwell (Ap) } \\
\hline \multicolumn{6}{|l|}{ Total $\mathbf{P}$} \\
\hline Soil P & $633 \pm 10$ & $635 \pm 11$ & $625 \pm 11$ & $717 \pm 10$ & $718 \pm 14$ \\
\hline Inorganic $\mathrm{P}$ & $285 \pm 7$ & $290 \pm 4$ & $265 \pm 7$ & $337 \pm 7$ & $370 \pm 7$ \\
\hline Organic $\mathrm{P}^{\dagger}$ & 348 & 345 & 360 & 380 & 348 \\
\hline \multicolumn{6}{|l|}{ Labile $\mathrm{P}$ indices } \\
\hline Resin-extractable P & $49.1 \pm 3.7$ & $51.3 \pm 4.1$ & $40.4 \pm 3.0$ & $95.6 \pm 16.8$ & $117.1 \pm 18.6$ \\
\hline Solution P & 0.84 & 1.09 & 0.45 & 5.25 & 10.25 \\
\hline $\mathrm{NaHCO}_{3}$-extractable $\mathrm{P}$ & $18.0 \pm 1.3$ & $15.8 \pm 0.9$ & $4.5 \pm 0.8$ & $33.7 \pm 2.1$ & $48.8 \pm 3.1$ \\
\hline
\end{tabular}

$\uparrow \mathrm{P}$ added $=81 \mu \mathrm{g} \cdot \mathrm{g}^{-1}$ soil.

$\div$ By difference. 
position rates of the added organic matter and steady state conditions, showed differences for each soil. The $P_{i}$ concentration decreased with the addition of cellulose in the Oxbow $\mathrm{Bm}$ soil and reached very low levels $(<1$ $\mu \mathrm{g} \cdot \mathrm{g}^{-1}$ soil) by the end of 30 days and remained at these low levels throughout 150 days of incubation. $\mathrm{P}_{\mathrm{m}}$ values consistently increased over the first 4 days of incubation following cellulose addition despite the fact that $P_{i}$ values were extremely low. In contrast, $P_{0}$ values tended to decrease at the time of maximum $\mathrm{P}_{\mathrm{m}}$ uptake and to increase in $\mathrm{P}_{\mathrm{o}}$ at the steady state stage.

The initial $P_{m}$ values were over $50 \%$ higher in the Bradwell soil than in the Oxbow Bm soil and showed a similar if less distinct pat- tern during the first three incubation periods. Thereafter, $P_{m}$ values did not show a distinctive pattern. $P_{i}$ values in the treatment where $C$ was added without $P$ decreased from 18.0 to $13.2 \mu \mathrm{g} \cdot \mathrm{g}^{-1}$ during the first 5 days of incubation and then decreased more slowly over the remaining 9-mo incubation to 4.5 $\mu \mathrm{g} \cdot \mathrm{g}^{-1}$. Where $\mathrm{C}$ was added with $\mathrm{P}, \mathrm{P}_{\mathrm{t}}$ values increased with each incubation to 32.7 $\mu \mathrm{g} \cdot \mathrm{g}^{-1}$.

Microbial $\mathrm{C} / \mathrm{P}$ ratios calculated from these observations (Table 6) reflect the fact that biomass values were similar in both soils with $\mathrm{C}$ addition, but $\mathrm{P}_{\mathrm{m}}$ production was greater in the Bradwell soil. Addition of $\mathrm{P}$ to both soils lowered $\mathrm{C} / \mathrm{P}$ ratios; addition of $\mathrm{C}$ without $\mathrm{P}$ increased $\mathrm{C} / \mathrm{P}$ ratios. Biomass $\mathrm{C}$ and $\mathrm{P}_{\mathrm{m}}$

Table 5. Organic and inorganic $P$ fractionation data in the original soils and after 9 mo of incubation. All results are expressed as $\mu \mathrm{g} \mathrm{P} \cdot \mathrm{g}^{-1}$ oven-dry soil and are the average of three determinations of each of three replicates $( \pm$ SD)

\begin{tabular}{|c|c|c|c|c|c|}
\hline & $\begin{array}{l}\text { Original } \\
\text { soil }\end{array}$ & $\begin{array}{c}\text { Control } \\
\text { soil }\end{array}$ & $\begin{array}{c}\text { Cellulose }+\mathrm{N}- \\
\text { treated soil } \\
\end{array}$ & $\begin{array}{c}\text { Cellulose }+\mathrm{N}+\mathrm{P}-\mathrm{t} \\
\text { treated soil }\end{array}$ & $\begin{array}{c}\text { P-treated } \dagger \\
\text { soil } \\
\end{array}$ \\
\hline & & & $\mu g \cdot g$ & & \\
\hline \multicolumn{6}{|c|}{ Oxbow $(B m)$} \\
\hline $\begin{array}{l}\mathrm{NH}_{4} \mathrm{Cl} \text {-extractable } \mathrm{P} \\
\mathrm{NH}_{4} \mathrm{~F} \text {-extractable } \mathrm{P} \\
\mathrm{NaOH}-\mathrm{NaCl} \text {-extractable } \mathrm{P} \\
\text { Reductant-soluble P } \\
\mathrm{NaOH} \text {-extractable P }\end{array}$ & $\begin{array}{r}0.4 \pm 0.0 \\
5.8 \pm 0.2 \\
9.8 \pm 0.4 \\
13.2 \pm 0.3 \\
17.8 \pm 0.2\end{array}$ & $\begin{array}{r}0.5 \pm 0.2 \\
9.8 \pm 0.6 \\
10.7 \pm 0.9 \\
14.8 \pm 2.5 \\
15.6 \pm 1.8\end{array}$ & $\begin{array}{r}0.4 \pm 0.1 \\
5.8 \pm 0.6 \\
9.5 \pm 1.1 \\
14.4 \pm 0.3 \\
14.7 \pm 1.4\end{array}$ & $\begin{array}{r}5.7 \pm 0.2 \\
38.7 \pm 0.4 \\
21.0 \pm 0.4 \\
20.2 \pm 2.6 \\
17.6 \pm 6.7\end{array}$ & $\begin{array}{l}11.8 \pm 0.2 \\
55.6 \pm 4.6 \\
25.1 \pm 0.5 \\
21.9 \pm 1.0 \\
19.0 \pm 1.8\end{array}$ \\
\hline $\begin{array}{l}\text { Organic P fractions } \\
\mathrm{H}_{2} \mathrm{SO}_{4} \text {-extractable } \mathrm{P} \\
\text { Alkali-hydrolyzable } \\
\text { Fulvic P } \\
\text { Humic P } \\
\text { Humin P\$ }\end{array}$ & $\begin{array}{l}47.5 \pm 2.5 \\
30.5 \pm 0.5 \\
42.5 \pm 1.5 \\
105.0 \pm 3.0 \\
\quad 87.5\end{array}$ & $\begin{array}{l}47.0 \pm 1.0 \\
24.3 \pm 3.0 \\
61.7 \pm 1.0 \\
99.5 \pm 3.2 \\
\quad 78.5\end{array}$ & $\begin{array}{l}49.0 \pm 0.0 \\
16.8 \pm 2.2 \\
17.2 \pm 0.8 \\
95.6 \pm 0.6 \\
91.4\end{array}$ & $\begin{array}{l}60.0 \pm 4.5 \\
12.8 \pm 1.8 \\
79.2 \pm 3.8 \\
96.0 \pm 4.2 \\
87.0\end{array}$ & $\begin{array}{l}42.0 \pm 2.0 \\
20.0 \pm 2.0 \\
66.0 \pm 0.5 \\
101.7 \pm 3.7 \\
87.3\end{array}$ \\
\hline \multicolumn{6}{|c|}{ Bradwell (Ap) } \\
\hline $\begin{array}{l}\text { Inorganic P fractions } \\
\mathrm{NH}_{4} \mathrm{Cl} \text {-extractable } \mathrm{P} \\
\mathrm{NH}_{4} \mathrm{~F} \text {-extractable } \mathrm{P} \\
\mathrm{NaOH} \text {-NaCl-extractable } \mathrm{P} \\
\text { Reductant-soluble } \mathrm{P} \\
\mathrm{NaOH} \text {-extractable } \mathrm{P}\end{array}$ & $\begin{array}{r}6.9 \pm 0.3 \\
36.5 \pm 0.2 \\
25.6 \pm 0.7 \\
14.2 \pm 1.0 \\
13.1 \pm 0.9\end{array}$ & $\begin{array}{r}7.5 \pm 0.5 \\
37.1 \pm 1.2 \\
25.8 \pm 0.2 \\
13.9 \pm 0.1 \\
13.6 \pm 1.4\end{array}$ & $\begin{array}{r}2.8 \pm 0.6 \\
25.1 \pm 2.0 \\
23.5 \pm 0.4 \\
13.8 \pm 0.3 \\
13.3 \pm 1.4\end{array}$ & $\begin{array}{l}21.9 \pm 1.0 \\
61.6 \pm 1.4 \\
32.1 \pm 0.9 \\
15.6 \pm 0.3 \\
13.3 \pm 0.4\end{array}$ & $\begin{array}{l}28.4 \pm 1.0 \\
71.7 \pm 1.5 \\
33.5 \pm 0.2 \\
17.9 \pm 0.9 \\
15.3 \pm 2.0\end{array}$ \\
\hline $\begin{array}{l}\text { Organic P fractions } \\
\mathrm{H}_{2} \mathrm{SO}_{4} \text {-extractable } \mathrm{P} \\
\text { Alkali-hydrolyzable } \\
\text { Fulvic P } \\
\text { Humic P } \\
\text { Humin P\$ }\end{array}$ & $\begin{array}{r}79.0 \pm 1.0 \\
30.0 \pm 2.5 \\
70.5 \pm 1.0 \\
107.0 \pm 4.0 \\
61.4\end{array}$ & $\begin{array}{c}79.5 \pm 0.5 \\
25.5 \pm 1.5 \\
96.0 \pm 2.0 \\
85.0 \pm 3.0 \\
57.0\end{array}$ & $\begin{array}{r}81.8 \pm 3.2 \\
22.3 \pm 0.8 \\
116.8 \pm 3.7 \\
83.5 \pm 4.5 \\
63.6\end{array}$ & $\begin{array}{r}86.3 \pm 6.2 \\
23.5 \pm 2.0 \\
129.5 \pm 5.0 \\
79.5 \pm 3.5 \\
61.2\end{array}$ & $\begin{array}{l}77.0 \pm 3.0 \\
25.3 \pm 2.2 \\
97.8 \pm 1.8 \\
83.5 \pm 2.0 \\
64.4\end{array}$ \\
\hline
\end{tabular}

$+\mathrm{P}$ added $=81 \mu \mathrm{g} \cdot \mathrm{g}^{-1}$.

Other inorganic $\mathrm{P}$ fraction; $\mathrm{H}_{2} \mathrm{SO}_{4}-\mathrm{P}$ not shown as relatively constant.

$\$$ By difference. 
values were not significantly correlated. Microbial $\mathrm{P}_{\mathrm{m}}$ values were significantly correlated $(P>0.001)$ to solution $\mathrm{P}$ values over the complete sampling period.

ATP values taken at each sampling date (Fig. 2) show that the values obtained in the Oxbow soil were generally lower than those obtained in the Bradwell soil. In the Bradwell soil the ATP values obtained from the $C$ additions were consistently higher than the control or P-alone treatments. Addition of $\mathrm{P}$ with $\mathrm{C}$ did not change the ATP levels from those obtained with $\mathrm{C}$ alone. In the Oxbow soil the ATP levels from all treatments were closer, but the $\mathrm{C}$ additions with $\mathrm{P}$ produced higher ATP values than $C$ additions without $P$; these, in turn, were consistently higher than treatments that did not receive $P$. Calculated microbial C/ATP data (Table 7) reflect the fact that ATP levels in the Bradwell soil were higher than in the Oxbow soil and the fact that the microbial $C$ values were comparable in both soils with similar $\mathrm{C}$ additions. Mean microbial C:ATP ratios obtained for control treatments were 281 and 203, respectively, in the Oxbow and Bradwell soils. Addition of $\mathrm{C}$ without $\mathrm{P}$ increased the average C:ATP ratio to 460 in the Oxbow soil and to 257 in the Bradwell soil. Addition of $\mathrm{P}$ with $\mathrm{C}$ con- sistently decreased the microbial C:ATP ratios. The magnitude of this decrease was greater in the Oxbow soil of low available $P_{i}$ status.

\section{DISCUSSION}

The results obtained in this study are best discussed with reference to a flow diagram of the $P$ cycle. This diagram (Fig. 3) conceptualizes solution $P$ originating from the very slow weathering or primary $\mathrm{P}$ minerals (mainly hydroxyapatites in the soils under study) and being held in equilibrium with the labile $P_{i}$ pool. In more weathered soils there will be a concurrent flow into secondary $\mathrm{P}$ minerals and some of these minerals may be occluded by Fe deposition on surfaces as weathering intensity increases (Smeck 1973). In neutral soils, flows into secondary $\mathrm{P}$ minerals are small and the main flow is into the labile $\mathrm{P}_{\mathrm{i}}$ pool. The distribution of added $P$ between solution and labile $\mathrm{P}_{\mathrm{i}}$ depends on the capacity factor $b$ (resin $\mathrm{P} /$ solution $\mathrm{P}=b$ ) which Olsen and Watanabe (1963) showed to be relatively constant in many soils over the normal range of $\mathrm{P}$ fertilization (additions of $\mathrm{P}$ to 25 $\left.\mu \mathrm{g} \cdot \mathrm{g}^{-1}\right)$.

No significant change was noted in hydroxy apatite-P during the 9-mo incuba-

Table 6. Microbial $\mathrm{C} / \mathrm{P}$ ratios ${ }_{\dagger}^{\dagger}$ at sampling dates in each 30-day incubation corresponding to maximum $\mathrm{CO}_{2}$ production. Values presented are the mean of duplicate samples

\begin{tabular}{|c|c|c|c|c|c|c|c|}
\hline \multirow[b]{2}{*}{ Treatment } & \multicolumn{5}{|c|}{ Sanıpling time (days) } & \multirow[b]{2}{*}{ Meant } & \multirow[b]{2}{*}{ Means } \\
\hline & 20 & 34 & 64 & 94 & 124 & & \\
\hline \multicolumn{8}{|c|}{ Oxbow (Bm) } \\
\hline Control & 39 & 8 & 29 & 10 & 20 & 21 & 26 \\
\hline Soil $+\mathrm{P}$ & 12 & 8 & 28 & 6 & 14 & 14 & 17 \\
\hline Cellulose $+\mathrm{N}$ & 37 & 19 & 27 & 22 & 54 & 32 & 45 \\
\hline Cellulose $+\mathrm{N}+\mathrm{P}$ & 22 & 12 & 34 & 22 & 22 & 22 & 29 \\
\hline \multicolumn{8}{|c|}{ Bradwell (Ap) } \\
\hline Control & 40 & 12 & 10 & 6 & 5 & 15 & 16 \\
\hline Soil + P & 28 & 10 & 7 & 6 & 5 & 11 & 12 \\
\hline Cellulose $+\mathrm{N}$ & 56 & 14 & 12 & 17 & 22 & 24 & 21 \\
\hline Cellulose $+\mathrm{N}+\mathrm{P}$ & 41 & 17 & 10 & 11 & 12 & 18 & 16 \\
\hline
\end{tabular}

† Microbial P extracted by $\mathrm{CHCl}_{3} / \mathrm{NaHCO}_{3}$ extraction was assumed to be $25 \%$ of the total microbial $\mathrm{P}$ (Hedley and Stewart unpubl. data).

\$ Mean $\mathrm{C} / \mathrm{P}$ ratios at maximum $\mathrm{CO}_{2}$ production sampling times.

$\$$ Mean $\mathrm{C} / \mathrm{P}$ ratios at all sampling dates. 
a) BRADWELL (AP)
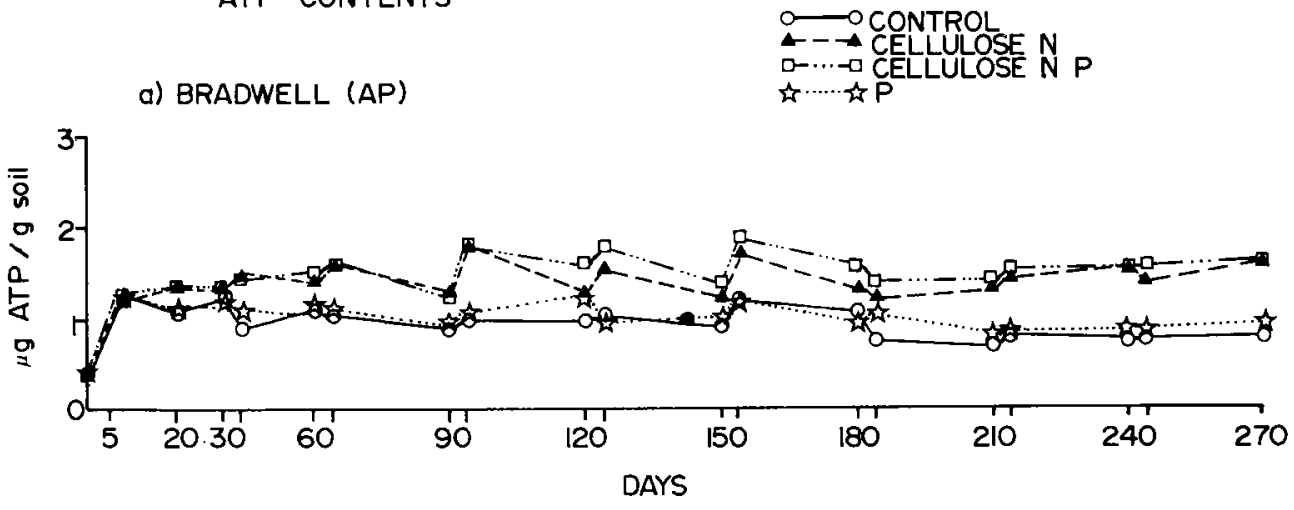

b) OXBOW (BM)

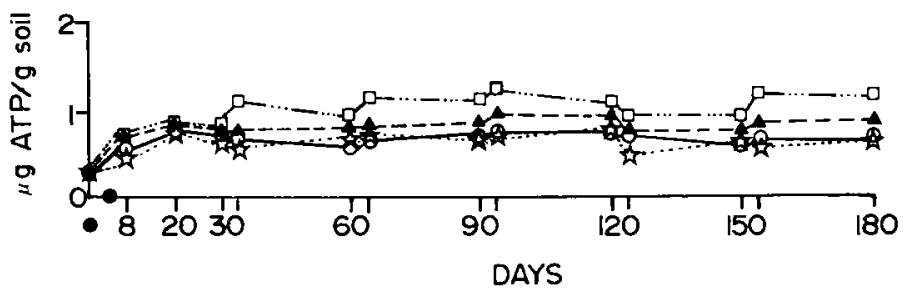

Fig. 2. ATP contents in both soils measured in four treatments with time.

tion. Small amounts of added $\mathrm{P}$ were found as secondary $\mathrm{P}_{i}$ minerals in the more acid soil (Oxbow Bm) and most of the added $P$ was found in the labile $P_{i}$ pool. The capacity factor of both control soils was not affected by incubation, but did change when cumula- tive amounts of added $\mathrm{P}$ became large (Fig. 4). The capacity factor of the Oxbow soil remained approximately constant at 95 until the cumulative addition of added $P$ was approximately $27 \mu \mathrm{g} \cdot \mathrm{g}^{-1}$. Thereafter, it decreased steadily to approximately 50 when 81

Table 7. Microbial C/ATP ratios at different sampling dates in two soils incubated with different $\mathrm{C}$ or $\mathrm{P}$ amendments. (Sampling dates chosen represented maximum $\mathrm{CO}_{2}$ activity and steady state activity in each 30-day incubation period)

\begin{tabular}{|c|c|c|c|c|c|c|c|c|c|}
\hline \multirow[b]{2}{*}{ Treatment } & \multicolumn{8}{|c|}{ Sampling time (days) } & \multirow[b]{2}{*}{$\bar{X}$} \\
\hline & 5 & $20 \dagger$ & 30 & $34 \div$ & 90 & $94 \dagger$ & 120 & $124 \dagger$ & \\
\hline \multicolumn{10}{|c|}{ Oxbow $(B m)$} \\
\hline Control & 274 & 283 & 261 & 439 & 270 & 253 & 224 & 247 & 281 \\
\hline Cellulose $+\mathrm{N}$ & 316 & 517 & 360 & 475 & 525 & 392 & 492 & 604 & 460 \\
\hline Cellulose $+\mathrm{N}+\mathrm{P}$ & 600 & 372 & 348 & 354 & 265 & 332 & 432 & 421 & 390 \\
\hline \multicolumn{10}{|c|}{ Bradwell (Ap) } \\
\hline Control & 209 & 206 & 145 & 346 & 173 & 213 & 144 & 190 & 203 \\
\hline Cellulose $+\mathrm{N}$ & 260 & 377 & 167 & 363 & 188 & 202 & 237 & 264 & 257 \\
\hline Cellulose $+\mathrm{N}+\mathrm{P}$ & 222 & 209 & 612 & 349 & 169 & 220 & 275 & 220 & 220 \\
\hline
\end{tabular}

$\div$ Maximum $\mathrm{CO}_{2}$ activity. 


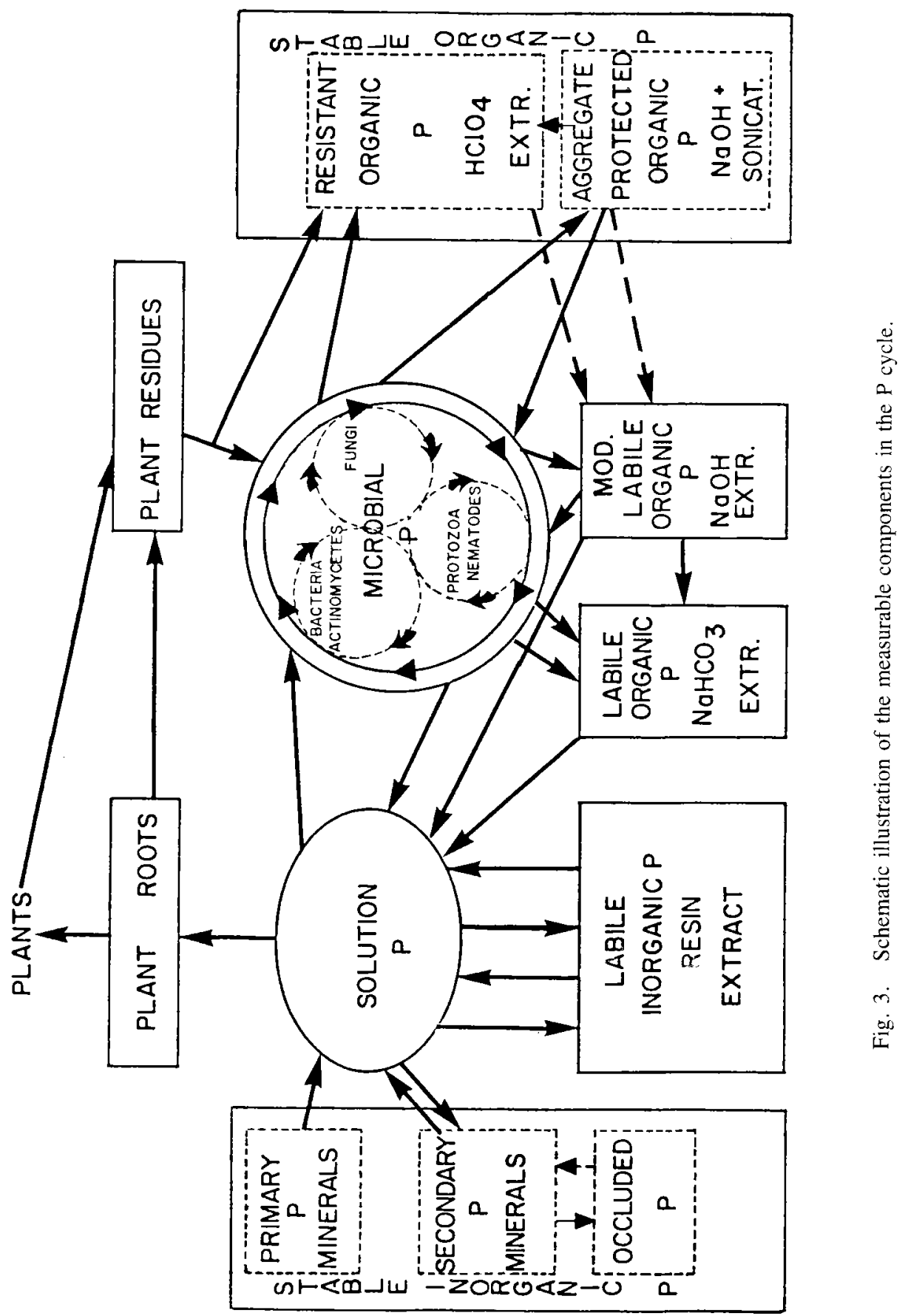



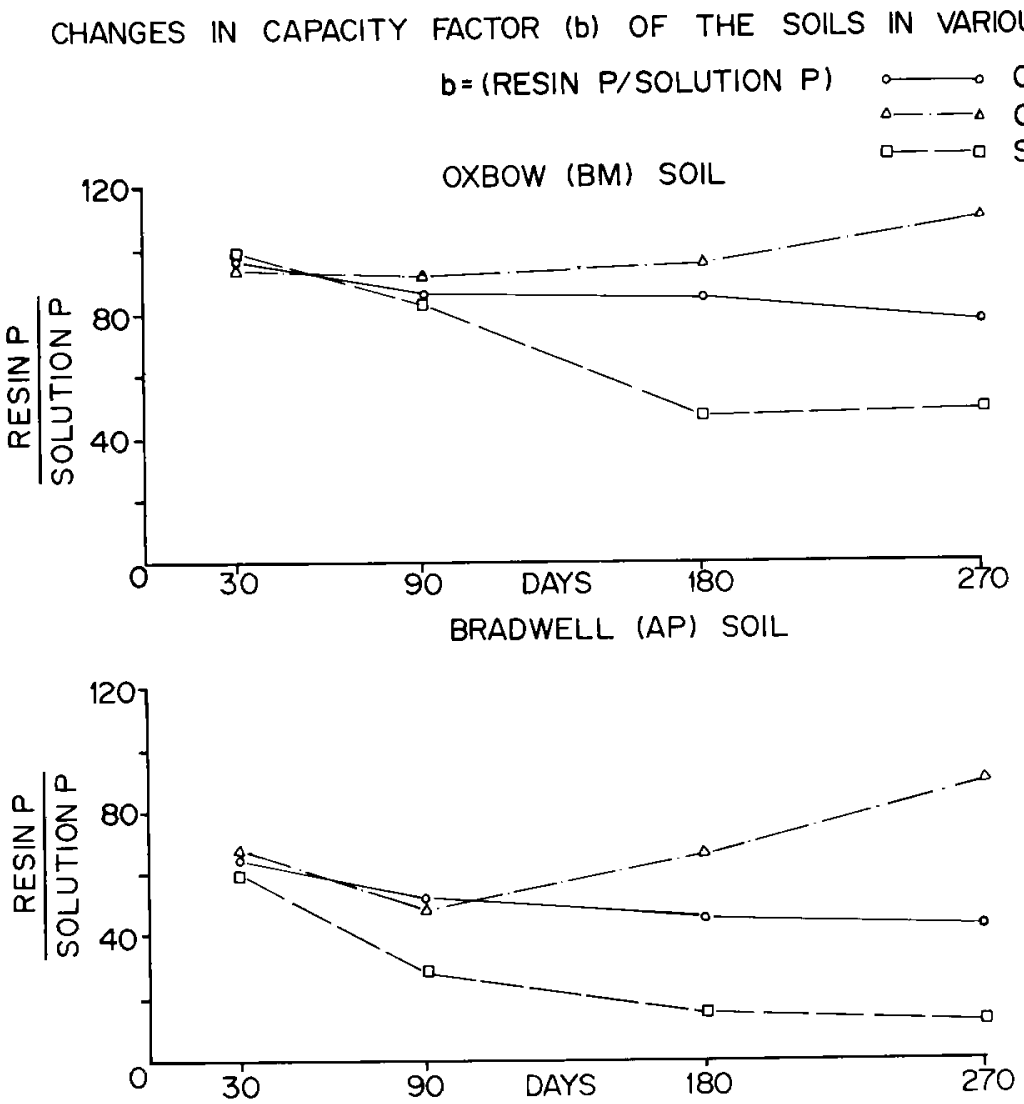

Fig. 4. Changes in the capacity factor of both soils with treatment and time.

$\mu \mathrm{g} \cdot \mathrm{g}^{-1}$ had been added without cellulose. With $\mathrm{C}$ and $\mathrm{P}$ additions the decrease in capacity factor reduction was slower and was approximately 70 after incubation and cumulative $\mathrm{P}$ additions of $81 \mu \mathrm{g} \cdot \mathrm{g}^{-1}$. Additions of $\mathrm{C}$ without $\mathrm{P}$ did not cause much change in the capacity factor of well-buffered Oxbow soil. In the Bradwell soil, cumulative $C$ addition increased the capacity factor, whereas cumulative $P$ additions decreases it from its original value of 60 . This means that the addition of extra fertilizer $P$ would be divided initially among these two pools and that the increase in solution $P$ resulting from addition of $9 \mu \mathrm{g} \mathrm{P} \cdot \mathrm{g}^{-1}$ would be greater in the Bradwell soil than in the Oxbow soil.
Higher solution $\mathrm{P}$ caused a greater uptake of $\mathrm{P}$ by the microbial populations. The $\mathrm{P}_{\mathrm{m}}$ so accumulated would eventually be released (either through amoebal and nematode grazing as shown by Cole et al. (1978), or by death of microbial cells) releasing the contents of the microbial cell (RNA 30-50\%, acid-soluble inorganic and organic $\mathrm{P}$ compounds $15-20 \%$, consisting of ortho-meta, sugar, and adenosine phosphates, and various phosphorylated coenzymes, phospholipides $<10 \%$; and DNA 5-10\%) to react with soil colloidal material. The rate of mineralization of the $P_{o}$ released in this process will depend on phosphatase activity and on the type of $P_{o}$ compound released (McKercher and Tol- 
lefson 1978). Phosphatase production activity is inversely related to solution $\mathrm{P}$ concentrations (Speir and Ross, 1978).

Results obtained showed that microbial $\mathrm{C}: \mathrm{P}$ ratios were closely correlated with solution $\mathrm{P}$, with ratios as low as $12: 1$ and as high as 45:1 being recorded. Where solution $P$ was low, the $\mathrm{NaHCO}_{3}-\mathrm{P}_{0}$ values were found to fluctuate markedly and to decrease at times of maximum $\mathrm{P}_{\mathrm{m}}$ production: when solution $\mathrm{P}$ was high, few changes in $\mathrm{NaHCO}_{3}-\mathrm{P}_{0}$ were observed. Net changes in $\mathrm{P}_{0}$ composition upon treatment and incubation generally increased the fulvic acid $\mathrm{P}$ at the expense of alkali hydrolyzable and humic $\mathrm{P}$. This would agree with the ideas presented by Anderson (1979) and McGill and Cole (in press). They postulated that the soil would contain a variable reserve of $P_{0}$ that is associated with humic material. This reserve would differ as a function of both soil genesis and demand. Unfortunately, the changes in fulvic, humic and other $\mathrm{P}_{\mathrm{o}}$ extracts were measured only at the end of 270 days of incubation and were not carried out after each 30-day incubation. Future work will attempt to measure these changes with time.

ATP values reflected both substrate and $P$ availability with the result that average microbial C:ATP ratios ranged from 203:1 to 460:1. These values are considerably higher than the ratio proposed by Jenkinson et al. (1979) for soil organisms where no recent substrate has been added; however, the latter authors used a different ATP extraction technique. Low quantities of both solution $P$ and labile $P_{i}$ eventually slowed down the rate of decomposition of added cellulose in the Oxbow soil although an increased mineralization of $P_{o}$ partially compensated for the low $P_{i}$ values. Decomposition of added cellulose was also curtailed in the Bradwell soil after the $\mathrm{NaHCO}_{3} \mathrm{P}_{\mathrm{i}}$ had been reduced.

Incubation of the soils without $\mathrm{C}$ or $\mathrm{P}$ additions did not cause significant changes in $P_{i}$ or $P_{o}$ forms but did increase the amount of $P_{o}$ extracted as fulvic $-\mathrm{P}$ at the expense of humic $\mathrm{P}$ and alkali-hydrolyzable forms. Incubation with added $C$ resulted in increases in total $P_{0}$ at the expense of total $P_{i}$. Most of the $P_{i}$ converted to $P_{o}$ came from labile $P_{j}$ forms in the Bradwel soil; but in the Oxbow soil, which did not have a large labile $P_{i}$ pool, more unavailable forms of $\mathrm{P}_{\mathrm{i}}$ appeared to have been utilized.

Added $\mathrm{P}$ was immobilized and redistributed in both inorganic and organic forms. The availability of solution had a marked effect on the forms of labile $P_{o}$ measured in the soil with time. When an energy source was added without added $\mathrm{P}, \mathrm{P}$ was immobilized from the various $P_{i}$ forms and redistributed in the soil partially as $P_{0}$. When $P$ was added without an energy source it accumulated in $P_{i}$ forms with no change in net $P_{0}$. This study documents the type of $P$ redistribution that can occur in soil and provides an explanation for seasonal variation in soil $\mathrm{P}_{\mathrm{o}}$ observed by many authors in western Canadian soils.

\section{ACKNOWLEDGMENTS}

The authors gratefully acknowledge the financial support provided by the National Science and Engineering Research Council of Canada for part of this research, and to the Government of India Ministry of Education for the award of a National Scholarship to the senior author.

ALLISON, L. E. 1965. Organic carbon. In C. A. Black, ed. Methods of Soil Analysis. Part 2. Amer. Soc. Agron., Inc., Madison, Wis.

ANDERSON, D. W. 1979. Processes of humus formation and transformation in soils of the Canadian Great Plains. J. Soil Sci. 30: 77-89.

ANDERSON, G. 1975. Organic phosphorus compounds. Pages 305-334 in J. E. Gieseking, ed. Soil components, Vol. I. Springer Verlag, N.Y. BABIUK, L. A. and PAUL, E. A. 1970. The use of fluorescein isothiocyanate in the determination of the bacaterial biomass of grassland soils. Can. J. Microbiol. 16: 57-62.

BOWMAN, R. A. and COLE, C. V. $1978 \mathrm{a}$. Transformations of organic phosphorus substrates in soils evaluated by $\mathrm{NaHCO}_{3}$ extraction. Soil Sci. 125: $49-54$.

BOWMAN, R. A. and COLE, C. V. 1978b. An exploratory method for fractionation of organic phosphorus from grassland soils. Soil Sci. 125: 95-101. 
CANADA SOIL SURVEY COMMITTEE, SUBCOMMITTEE ON SOIL CLASSIFICATION 1978. The Canadian system of soil classification. Can. Dep. Agric. Publ. 1646. Supply and Services Canada, Ottawa. 164 pp.

CHAUHAN, B. S., STEWART, J. W. B. and PAUL, E. A. 1979. Effect of carbon additions on soil labile inorganic, organic and microbially held phosphate. Can. J. Soil Sci. 59: 387-396.

COLE, C. V., ELLIOTT, E. T., HUNT, H. W. and COLEMAN, D. C. 1978. Trophic interactions in soils as they affect energy and nutrient dynamics. V. Phosphorus transformations. Microb. Ecol. 4: 381-387.

COLE, C. V., INNIS, G. I. and STEWART, J. W. B. 1977. Simulation of phosphorus cycling in semi-arid grasslands. Ecology 58: 1-15.

COSGROVE, D. J. 1977. Microbial transformation in the phosphorus cycle. Pages 97-134 in M. Alexander, ed. Advances in microbial ecology. Plenum Press, New York.

HALM, B. J., STEWART, J. W. B. and HALSTEAD, R. L. 1972. The phosphorus cycle in a native grassland ecosystem. Pages 571-586 in Isotopes and radiation in soil plant relationships including forestry. SM151/7. IAEA, Vienna.

HALSTEAD, R. L. and McKERCHER, R. B. 1975. Biochemistry and cycling of phosphorus. Pages 31-63 in E. A. Paul and R. A. D. McLaren, eds. Soil biochemistry, Vol. 4, Ch. 2. Marcel Dekker, New York.

JENKINSON, D.S., DAVIDSON, S. A. and POWLSON, D. S. 1979. Adenosine triphosphate and microbial biomass in soil. Soil Biol. Biochem. 11: $521-527$.

JENKINSON, D.S. and POWLSON, D. S. 1976. The effects of biocidal treatments on metabolism in soil. V. A method for measuring soil biomass. Soil Biol. Biochem. 8: 209-213.

McGILL, W. B. and COLE, C. V. 1981 Comparative aspects of organic $\mathrm{C}, \mathrm{N}, \mathrm{S}$ and $\mathrm{P}$ cycling through soil organic matter during pedogenesis. Geoderma. In Press.

McKERCHER, R. B. and TOLLEFSON, T. S. 1978. Barley response to phosphorus from phospholipids and nucleic acids. Can. J. Soil Sci. 58: 103-105.
OLSEN, S. R., COLE, C. V., WATANABE, F. S. and DEAN, L. A. 1954. Estimation of available phosphorus in soils by extraction with sodium bicarbonate. U.S. Dep. Agric. Circ. 939.

OLSEN, S. R, and WATANABE, F. S. 1963. Diffusion of phosphorus as related to soil texture and plant uptake. Soil Sci. Soc. Amer. Proc. 27: 648-653.

PAUL, E. A. and JOHNSON, R. L. 1977. Microscopic counting and adenosine 5 'triphosphate measurement in determining microbial growth in soils. Appl. Environ. Microbiol. 34: 263-269.

PETERSON, G. W and COREY, R. B. 1966. A modified Chang and Jackson procedure for routine fractionation of inorganic soil phosphate. Soil Sci. Soc. Am. Proc. 30: 563-565.

SADLER, J. M. and STEWART, J. W. B. 1975. Changes with time in form and availability of residual fertilizer phosphorus in a catenary sequence of chernozemic soils. Can. J. Soil Sci. 55: 149-159.

SADLER, J. M. and STEWART, J. W.B. 1977. Labile residual fertilizer phosphorus in chernozemic soils. I. Solubility and quantity/intensity studies. Can. J. Soil Sci. 57: 65-73.

SAUNDERS, W. M. H. and WILLIAMS, E. G. 1955. Observations on the determination of total organic phosphorus in soils. J. Soil Sci. 6: 245-267.

SIBBESEN. E. 1977. A simple ion-exchange procedure for extracting plant-available elements from soil. Plant Soil 46: 665-669.

SMECK, N. E. 1973. Phosphorus: an indicator of pedogenic weathering progress. Soil Sci. 115: 199-206.

SPEIR, T. W. and ROSS, D. J. 1978. Soil phosphatase and sulphatase. Pages 197-250 in R. G. Burns, ed. Soil enzymes. Academic Press Inc., London.

Van VEEN, J. A. and PAUL, E. A. 1979. Conversion of biovolume measurement of soil organisms grown under various moisture tensions to biomass and their nutrient content. Appl. Environ. Microbiol. 37: 686-692. 